\title{
Europeanisation of Nordic Civil \\ Procedure: Does the Map Match the Terrain?
}

\author{
Anna Nylund
}

\begin{abstract}
EU law has a tangible influence on the civil procedure law in the Nordic countries. This chapter explores how EU civil procedure law is practised and perceived in the Nordic countries. First, a brief account of the manifold levels and types of EU civil procedure law is given. The extent to which Nordic legal academics, judges and legal counsel make use of and discuss EU civil procedure law is analysed. A key question is whether lawyers appear to have a relatively superficial knowledge of EU law (i.e., they identify only central issues) or whether they have acquired profound skills (i.e., they are able to identify and address complex issues). Third, the transposition of EU hard law and case law into national civil procedure law in the Nordic countries is examined. The Nordic countries generally implement EU hard law diligently, at least formally. Nevertheless, it will be argued that the quality of implementation is sufficient and that case law-based rules are often inadequately transposed. Finally, the consequences of a superficial approach to EU civil procedure law in the Nordic countries are discussed.
\end{abstract}

\section{Introduction to Europeanisation of Civil Procedure}

\subsection{Introductory Remarks}

Since the 1990s, European law has continuously shaped Nordic civil procedural law. Three waves of Europeanisation can be identified. The first wave was the requirements of a fair trial and other human rights enshrined in the European Convention on Human Rights (ECHR) that have been transmitted through the case law of the European Court of Human Rights (ECtHR). This wave brought procedural human rights

\footnotetext{
A. Nylund $(\varangle)$

UiT, The Arctic University of Norway, Hansine Hansens veg 18, 9037 Troms $\varnothing$, Norway

e-mail: anna.nylund@uit.no
} 
to the forefront of Nordic law, making the ECHR an integrated part of Nordic procedural law. ${ }^{1}$ The second wave, or rather a set of waves, emanates from European Union law, and comes in various forms: 'constitutional' law, regulations, directives, case law, soft law and international conventions regulating proceedings with cross-border elements, or that are designed to improve the enforcement of central EU policies, such as consumer and competition law. The third wave consists of networks, training, rankings, information portals and so forth, mainly within the domain of EU but also through the Council of Europe and other organisations. ${ }^{2}$

The first wave was an earthquake for criminal procedure. Additionally, it caused palpable changes to civil procedure argumentation because it highlighted the role of legal principles embodying various aspects of fair trial rights in legal argumentation, particularly in legal scholarship. ${ }^{3}$ In contrast, the second wave of European law has been creeping in more gradually: the legislation is voluminous and omnipresent, and yet many lawyers working in the field of procedural law are oblivious to it, or at least underestimate the magnitude of it, and its far-reaching implications. This chapter will explore the paradoxes of mismatching perceptions and realities of the nature and impact of EU procedural law in the Nordic countries. The study is limited to civil procedural law, since also covering criminal procedure would be both beyond the scope of this chapter and at least partly redundant, as some of the basic mechanisms apply there as well.

In this chapter, the nature and amount of EU law with relevance for civil procedure is briefly discussed in Sect. 2. Section 3 explores the Nordic response to EU civil procedure law among various stakeholders: scholars, judges and practitioners. Thereafter, transposition of EU hard law and case law in Nordic civil procedure law is analysed in Sect. 4. In the final Sect. 5, the ramifications of the discrepancies between the level of EU influences and Nordic perceptions of, and reactions to, EU civil procedure law are discussed.

\subsection{The Nordic Countries, the EU and the EEA Agreement}

In the area of Justice and Home Affairs, the Nordic countries have chosen different approaches to EU law. Finland and Sweden are bound by all EU law, whereas Denmark has an exemption from Justice and Home Affairs, as a result of the 1993 referendum where the Danish people rejected the Maastricht Treaty. Hence, EU law enacted to improve judicial cooperation in civil matters is not applicable in Denmark unless Denmark has used its right to opt in. In contrast, EU civil procedure

\footnotetext{
${ }^{1}$ See, e.g., Bang-Pedersen et al. (2017), pp. 67 ff., Bylander (2017), Frände et al. (2012), pp. 214 ff., Skoghøy (2011), pp. 4-24 and Ervo (2005).

${ }^{2}$ Storskrubb (2019a).

${ }^{3}$ Examples of doctoral disseratiotions from this period in the field of civil procedure where selected aspects of the European Convvention on Human Rights art. 6 is discussed in detail are Bernt (2011), Bylander (2006), Knuts (2006) and Ervo (2005).
} 
law, emanating from the duty to provide effective and equivalent protection of rights derived from EU law, efficient enforcement of EU consumer law and so forth, applies in Denmark.

Although Iceland and Norway are not EU Member States, the Agreement on the European Economic Area (EEA) extends a major part of EU law directly or indirectly to EEA/EFTA states. ${ }^{4}$ Iceland and Norway are not EU Member States but rather are bound by the EEA Agreement, which extends the single, internal market to the EEA states. The EEA Agreement is limited to the four freedoms of the Single Market (i.e., free movement of goods, capital, services and labour); consequently, Justice and Home Affairs are not included in it. The EEA Agreement contains a mechanism for incorporating EU law into the agreement, which creates an obligation for EEA states to implement EU law. Moreover, the EFTA Surveillance Authority (ESA) mirrors the EU Commission, and the EFTA Court has the role of the CJEU. EEA states are obliged to ensure homogenous application of EU law across the EU and EEA states. Courts in EEA countries have the right, but not a duty, to request Advisory Opinions from the EFTA Court on interpretation of EU law. ${ }^{5}$

Although the EEA Agreement as such does not cover Justice and Home Affairs, EEA states have by no means escaped Europeanisation. Firstly, the duty to effective and equivalent protection of rights derived from EU law applies in EEA states in the same manner as in EU Member States. ${ }^{6}$ Second, the EFTA Court has found that although the EU Fundamental Rights Charter has not been formally incorporated into the EEA Agreement, it is part of the general principles of law. ${ }^{7}$ Third, substantive law (e.g., consumer and competition law) sometimes has implications for procedural law and, hence, is applicable in the EEA states. Fourth, the Lugano Convention serves in practice as an extension of the Single Market, creating free movement of judgments. The Convention mirrors the Brussels I bis Regulation. Fifth, EEA states regularly implement EU procedural law voluntarily to ensure effective and equal protection of rights across the Single Market. For example, Norway has implemented the Intellectual Property Rights Enforcement Directive ${ }^{8}$ in the Dispute Act, ${ }^{9}$ even though the Directive has not been incorporated into the EEA Agreement. ${ }^{10}$

Interestingly, sometimes EEA states would like to participate in EU civil justice but are barred from doing so. The Unified Patent Court system is the paramount example,

\footnotetext{
${ }^{4}$ Nylund (2016, 2020), Fredriksen and Strandberg (2018) and Fredriksen (2008). For Iceland and Norway, the term EU/EEA law, and sometimes EU/EEA/Lugano or EU/EEA/EFTA law would be more accurate than EU law, but for simplicity EU law is used to refer to all categories.

${ }^{5}$ See, e.g., Fredrisken (2018), Poulsen (2016) and Fenger et al. (2012).

${ }^{6}$ E.g., Nylund (2020), Franklin (2018), Fredriksen and Strandberg (2018), Lang (2017), Fredriksen and Franklin (2015), Fredriksen (2010, 2012) and Temple Lang (2012).

${ }^{7}$ Spano (2017) and Björgvinsson (2014).

${ }^{8}$ Parliament and Council Directive 2004/48/EC of 29 April 2004 on the enforcement of intellectual property rights O.J. L157/48 (2004).

${ }^{9}$ Act relating to mediation and procedure in civil disputes (The Dispute Act) Lov om mekling og rettergang i sivile tvister (tvisteloven) of 17 June 2005 no. 90.

${ }^{10}$ See, e.g., Nylund (2020) and Fredriksen and Strandberg (2018).
} 
where the CJEU Opinion $1 / 09^{11}$ has been interpreted to preclude non-Member States from participating. ${ }^{12}$

The Nordic countries are a paramount example of multi-speed integration in judicial cooperation, with varied approaches to EU civil procedure law. The EEA Agreement adds a layer of complexity, since the Agreement might modify the application of EU law, or EU law may not be applicable at all. Similarly, some of the EU law on judicial cooperation in civil matters, such as the Brussels I bis Regulation, apply in Denmark. Despite these differences among the Nordic countries, the similarities are more striking than the differences, and many differences are more a matter of nuance than fundamental differences. ${ }^{13}$

\section{The Variegated European Civil Procedure Landscape}

The landscape of EU civil procedure law has been described and analysed in detail elsewhere ${ }^{14}$; thus, painting the landscape with a broad brush suffices here. Europeanisation exists on several levels. ${ }^{15}$

The first level consists of EU constitutional law, particularly article 47 of the EU Charter of Fundamental Rights, ${ }^{16}$ which includes the right to a fair trial. Additionally, the basic principles of EU law, primarily the principle of effective judicial protection, form part of EU constitutional law. The second level is EU hard law-directives and regulations, which come in many forms. Some of them have an overt civil procedure content that regulates mainly cross-border cases, such as the Brussels I bis Regulation $^{17}$ on jurisdiction and the recognition and enforcement of judgments in civil and commercial matters. Other EU regulations create distinct European procedures for cross-border cases that parallel national procedures such as the European Small Claims Regulation. ${ }^{18}$ A notable part of procedural hard law, however, is found in instruments with a primarily substantive content or instruments aiming for efficient enforcement of a particular type of rights, such as intellectual property rights or consumer rights. The third level of EU civil procedure law consists of Court of Justice of the European Union (CJEU) case law, in which the court develops procedural rules and doctrines, such as the requirements of effective and equivalent

\footnotetext{
${ }^{11}$ Opinion 1/09 of 8 March ECLI:EU:C:2011:123.

${ }^{12}$ For a discussion on the role of the Unified Patent Courts, see Petersen and Schovsbo (2018).

${ }^{13}$ Nylund (2020). Adler-Nissen (2015) argues that the Denmark and Norway are in very similar positions regarding legislation on the Area of Freedom, Security and Justice.

${ }^{14}$ E.g., Storskrubb (2019a) and Storskrubb (2008).

${ }^{15}$ Krans (2015).

${ }^{16}$ Charter of Fundamental Rights of the European Union O.J. C326/391 (2012).

${ }^{17}$ Regulation (EU) No 1215/2012 of the European Parliament and of the Council of 12 December 2012 on jurisdiction and the recognition and enforcement of judgments in civil and commercial matters O.J. L351/1 (2012).

${ }^{18}$ Regulation (EC) No 861/2007 of the European Parliament and of the Council of 11 July 2007 establishing a European Small Claims Procedure O.J. L199/1 (2007).
} 
protection of rights arising from EU law. ${ }^{19}$ Another example is the duty for courts to apply selected parts of EU consumer law on their own motion. Soft law, such as various recommendations, constitutes the fourth level. Finally, international treaties entangled in EU law, such as the 2007 Hague Convention on International Recovery of Child Support and other Family Maintenance, constitute the fifth level. ${ }^{20}$

The impact EU law asserts on national law is partly overt and direct. ${ }^{21}$ The requirement of effective and equivalent protection of rights emanating from EU law is generally recognised as a doctrine with direct implications for national civil procedure law. ${ }^{22}$ In cross-border cases, national courts must clearly adhere to the EU rules on cross-border taking of evidence and service of documents. The duty to implement collective redress mechanisms for private enforcement of competition law and alternative dispute resolution mechanisms in consumer cases is also indisputable.

Nevertheless, part of the impact of EU civil procedure law is less manifest. Several factors contribute to reducing the visibility of the potential impact on national law, among others the fact that the procedural rules are embedded in EU law seemingly regulating substantive law. For instance, regulations concerning, for instance, consumer and competition law include rules on the burden and standard of proof. The procedural content risks being neglected or considered accessory: regulations are often transposed in statutory law regulating the specific subject area and not integrated in the rules of civil procedure. Moreover, EU law is sometimes considered merely 'technical' in nature, with few, if any, long term ramifications for national law. $^{23}$

Case law-based rules also run the risk of remaining hidden in legislation-based legal cultures, since lawyers could be oblivious to the existence or implication of the rules, because they do not actively follow, or they misinterpret, CJEU case law.

EU civil procedure law has innate, covert features with potentially highly disruptive power. The criteria determining the identity of a case or the classification of a case, such as a family maintenance case or a labour case, could be discordant with national law. ${ }^{24}$ The classification and identity of a case have profound implications on several aspects of civil procedure law, such as the power and obligation of the court to act on its own motion and the rules on lis pendens and res judicata. Therefore, differences between national law and EU law could result in a need for significant modifications of national law.

If the interconnections and potential tensions between national law and European law are not made explicit, European civil procedure law risks becoming a jack-in-the-box that surfaces unexpectedly and uncontrollably. Thomas Wilhelmsson argued in the mid-1990s that the piecemeal, sectoral approach of EU law, where the

\footnotetext{
${ }^{19}$ Example, Prechal and Cath (2014), Bobek (2010), Storskrubb (2008), p. 15, and Dougan (2004), pp. 28-34.

${ }^{20}$ Nylund and Strandberg (2019a).

${ }^{21}$ Krans (2020).

${ }^{22}$ Example, Krans and Nylund (2020a, b), Bobek (2010), Storskrubb (2008) and Dougan (2004).

${ }^{23}$ E.g., Galič (2020) and Ervo (2020).

${ }^{24}$ E.g., Nylund (2017b), pp. 355-356.
} 
focus is on enforcing certain policies rather than on maintaining law as a coherent system, markedly increases the indeterminacy of law. ${ }^{25}$ EU law does not aspire to a coherent, hierarchical structure and lacks legal cultural roots, yet it is integrated into national law and legal culture that endeavours to be coherent. These 'hidden' elements in EU civil procedure law surface in a Member State at irregular intervals. Avoiding surprising encounters with EU law requires vigilance on the part of the legal community: policymakers, legislators, judges, legal counsel and academics. The question is how the Nordic legal community perceives and adapts to the European legal landscape.

\section{The Nordic Map of EU Civil Procedural Law}

\subsection{EU Civil Procedure in Legal Scholarship}

Based on Nordic research on Europeanisation of civil procedure published in English, the level of interest in the topic is high. ${ }^{26}$ Eva Storskrubb could be characterised as a trailblazer in building the foundations of European civil procedure law as a separate subfield of law situated at the crossroads of EU law and civil procedural law. ${ }^{27}$

There is also a considerable body of research that has been conducted in Nordic languages. ${ }^{28}$ Torbjörn Andersson was one of the pioneers of the field when he authored a two-volume dissertation in the mid-1990s on the influence of EU law on how competition law cases are handled in Swedish procedural law. ${ }^{29}$ Erik Werlauff explored the impact of EU law on Danish civil procedure in 1997. ${ }^{30}$ Halvard Haukeland Fredriksen's comparative study on the impact of requests for preliminary rulings on German civil procedure and the impact of requests for advisory opinions on Norwegian civil procedure was seminal, although due to the fact that it was written in German, it has reached a smaller Nordic audience. ${ }^{31}$ The considerable academic interest in the topic raises the question of whether the academic discussions translate into a high level of understanding among lawyers, judges and lawmakers.

\footnotetext{
${ }^{25}$ Wilhelmsson (1997).

${ }^{26}$ E.g., Nylund (2016, 2020), Nylund and Strandberg (2019b), Šadl and Wallerman (2019), Wallerman (2018, 2019a, b), Storskrubb (2018, 2019a, b), Franklin (2018), Fredriksen and Strandberg (2018), Petersen and Schovsbo (2018), Wind (2018), Storskrubb and Wallerman (2017), Derlén and Lindholm (2017a, b),Hess et al. (2016), Petersen (2016), Wallerman (2016a, b) and Linna (2015).

${ }^{27}$ Storskrubb (2008).

${ }^{28}$ E.g., Storskrubb (2017a, b), Lindfors (2017), Fredriksen (2011, 2016), Linna (2016) and Wallerman (2015).

${ }^{29}$ Andersson (1997).

${ }^{30}$ Werlauff (1997).

${ }^{31}$ Fredriksen (2009).
} 


\subsection{Courts and Judges Applying EU Law}

Courts constitute an important player in the Europeanisation of procedural law in at least two ways. First, national courts contribute to shaping EU law by requesting preliminary rulings. Second, national courts enforce EU law and hence play a pivotal role in the application of EU law and in making national law conform to the requirements of EU law.

The number of references for preliminary rulings from Nordic, in particular Swedish, courts has been debated. The EU Commission has investigated Finnish and Swedish courts for failure to refer cases. ${ }^{32}$ At the end of 2020, Danish courts had made a total of 144 references, Finnish courts 127 and Swedish courts 150. Icelandic courts have made 35 requests for advisory opinions and Norwegian courts 64 requests. Considering the more limited scope of the EEA Agreement and the more limited jurisdiction of the EFTA Court, it is hardly surprising that courts in EEA countries make fewer requests than courts in EU Member States do. Additionally, the population sizes explains some of the differences among the Nordic countries. In recent years, the number of requests from Norwegian courts has increased compared to earlier years, with an annual average of 3.6 requests for advisory opinions.

Several commentators, among others Halldóra Thorsteinsdóttir in this volume, ${ }^{33}$ have spotted at least some hesitation among Nordic courts in referring cases to the CJEU. ${ }^{34}$ However, based on an quantitative analysis of inter alia the number of incoming civil cases, population size and size of the economy, Morten Broberg and Niels Fenger argue that the number of requests for preliminary rulings is neither high nor low. ${ }^{35}$ The alleged disinclination of Nordic courts to request preliminary rulings could stem from many factors and should not be as such taken as a sign of Euroscepticism. The Nordic legal method entails harmonising arguments derived from different sources, which makes courts comfortable with conducting an independent analysis of the content of EU law and aligning national law with EU law through interpretation. ${ }^{36}$

Referring cases to the CJEU is akin to judicial review of statutory law in light of the constitution. In both cases, courts question whether statutory law should be disregarded due to the fact that it is incompatible with law of a higher rank. The fact that the historical attitude towards judicial review has been ambivalent except for review of formal aspects of statutes could explain a certain self-restraint both in the

\footnotetext{
${ }^{32}$ Miettinen (2019) and Bernitz (2012).

${ }^{33}$ Thorstensdóttir (2021).

${ }^{34}$ Miettinen (2019), Bernitz (2012, 2018), Derlén and Lindholm (2017b), Rytter and Wind (2011), Martinsen and Wind (2010), Wind (2009) and Wind et al. (2009). For Iceland and Norway, see Fredriksen (2016), Poulsen (2016), Barnard (2014), Magnússon (2014), Sigurbjörnsson (2014) and Hreinsson (2012).

${ }^{35}$ Broberg and Fenger (2013, 2015). For related arguments regarding Icelandic courts, see Björgvinsson (2007) and Örlygsson (2007).

${ }^{36}$ Bernitz (2018), p. 31. For an account of the Nordic legal methods, see, e.g., Helland and Koch (2014) and Boucht (2014).
} 
propensity to refer cases to the CJEU and in the form and content of the references made. ${ }^{37}$ The early 1990 s mark a clear shift in attitudes towards constitutional review, and today judicial review is acknowledged as a task of (at least) the Supreme Courts in all Nordic countries. ${ }^{38}$ As a consequence of more active judicial review nationally, the threshold for making request could decrease over time.

Mastering the art of framing the request for a preliminary ruling in a manner that makes sense to the CJEU is a prerequisite for getting a useful answer. Identifying the more complex issues of EU law and issues arising at the crossroads of national and EU law necessitates a profound knowledge of EU law. The same applies to exploiting the opportunities to contribute to the development of EU law through preliminary references. Several commentators have questioned whether Nordic judges possess the skills necessary to conduct a fertile dialogue with the CJEU. ${ }^{39}$

With regard to national courts applying EU law, Nordic courts do apply EU law. However, several authors have argued that while Nordic courts apply EU law diligently when EU law is clearly applicable and the requirements it poses are unambiguous, they fail to recognise more intricate and less obvious issues. ${ }^{40}$

In matters concerning civil justice, by the end of 2020, Nordic courts had made a total of 20 requests for preliminary rulings. Finnish courts had made eight requests, ${ }^{41}$ Swedish courts seven, ${ }^{42}$ and Danish courts five requests. ${ }^{43}$ The Nordic courts had

\footnotetext{
${ }^{37}$ Bernitz (2018) pp. 31 -33, Wind (2010, 2018),Sunnqvist (2014) and Martinsen and Wind (2010).

${ }^{38}$ Example, Sunnqvist (2021), Husa (2000, 2019), Helgadóttir (2011), Nergelius (2009), Ojanen (2009), Sand (2009) and Schaumburg-Müller (2009).

${ }^{39}$ Wallerman (2016b, 2018), Wind (2018), Derlén and Lindholm (2017a, b) and Jääskinen (2005).

${ }^{40}$ Wallerman (2016b, 2018), Wind (2018), Derlén and Lindholm (2017a, b), Sunnqvist (2014) and Hreinsson (2012). See also Leijon and Karlsson (2013).

${ }^{41}$ Case C-435/06 C ECLI:EU:C:2007:714, Case C-523/07 A ECLI:EU:C:2009:225, Case C-4/14 Christophe Bohez v Ingrid Wiertz ECLI:EU:C:2015:563, Case C-310/14 Nike European Operations Netherlands BV v Sportland Oy, in liquidation ECLI:EU:C:2015:690, Case C-521/14 SOVAG-Schwarzmeer und Ostsee Versicherungs-Aktiengesellschaft $v$ If Vahinkovakuutusyhtiö Oy ECLI:EU:C:2016:41, Case C-605/14 Virpi Komu, Hanna Ruotsalainen, Ritva Komu v Pekka Komu, Jelena Kоти ECLI:EU:C:2015:833, Case C-88/17 Zurich Insurance plc, Metso Minerals Oy v Abnormal Load Services (International) Ltd ECLI:EU:C:2018:558, Case C-433/18 MLv OÜ Aktiva Finants still pending.

${ }^{42}$ Case C-98/06 Freeport plc v Ole Arnoldsson ECLI:EU:C:2007:595, Case C-68/07 Kerstin Sundelind Lopez v Miguel Enrique Lopez Lizazo ECLI:EU:C:2007:740, Case C-111/08 SCT Industri $A B$ i likvidation v Alpenblume AB ECLI:EU:C:2009:419, Case C-147/12 ÖFAB, Östergötlands Fastigheter AB v Frank Koot, Evergreen Investments BV ECLI:EU:C:2013:490, Case C-445/15 PPU P v Q ECLI:EU:C:2015:763, Case C-554/17 Rebecka Jonsson v Société du Journal L'Est Républicain ECLI:EU:C:2019:124, Case C-198/18 CeDe Group AB v KAN sp. z o.o., in liquidation ECLI:EU:C:2019:1001.

${ }^{43}$ Case C-341/93 Danvarn Production v Schuhfabriken Otterbeck ECLI:EU:C:1995:239, Case C-18/02 Danmarks Rederiforening, acting on behalf of DFDS Torline A/S v LO Landsorganisationen i Sverige, acting on behalf of SEKO Sjöfolk Facket för Service och Kommunikation ECLI:EU:C:2004:74, Case C-39/02 Märsk Olie \& Gas v Firma M. de Haan en W. De Boer ECLI:EU:C:2004:615, Case C-49/12 The Commissioners for Her Majesty's Revenue \& Customs $v$ Sunico ApS, M \& B Holding ApS, Sunil Kumar Harwani ECLI:EU:C:2013:545, Case C-368/16 Assens Havn v Navigators Management (UK) Limited ECLI:EU:C:2017:546.
} 
requested the CJEU to opine on the Brussels I bis Regulation and its predecessors 13 times, ${ }^{44}$ the Brussels II bis Regulation ${ }^{45}$ and its predecessor five times, ${ }^{46}$ the insolvency proceedings regulation ${ }^{47}$ and its predecessor twice ${ }^{48}$ and the European Small Claims Regulation once. ${ }^{49}$ Of the four Regulations, only the Brussels I Regulation applies in Denmark. Thus, it is hardly surprising that the number of requests for preliminary rulings is lower from Danish courts. Since the EFTA Court does not have the power to interpret the Lugano Convention, Icelandic and Norwegian courts cannot request advisor opinions. Therefore, there are no such cases for the EEA countries.

Analysing requests for preliminary rulings and advisory opinions for procedural questions in other areas of law is beyond the scope of this chapter. However, an indepth analysis of possible procedural aspects included in requests concerning other areas of law could give additional insight.

\footnotetext{
${ }^{44}$ Case C-98/06 Freeport plc v Ole Arnoldsson ECLI:EU:C:2007:595, Case C-111/08 SCT Industri $A B$ i likvidation $v$ Alpenblume $A B$ ECLI:EU:C:2009:419, Case C-49/12 The Commissioners for Her Majesty's Revenue \& Customs v Sunico ApS, $M$ \& B Holding ApS, Sunil Kumar Harwani ECLI:EU:C:2013:545, Case C-147/12 ÖFAB, Östergötlands Fastigheter AB v Frank Koot, Evergreen Investments BV ECLI:EU:C:2013:490, Case C-4/14 Christophe Bohez v Ingrid Wiertz ECLI:EU:C:2015:563, Case C-521/14 SOVAG - Schwarzmeer und Ostsee VersicherungsAktiengesellschaft $v$ If Vahinkovakuutusyhtiö Oy ECLI:EU:C:2016:41, Case C-605/14 Virpi Komu, Hanna Ruotsalainen, Ritva Komu v Pekka Koти, Jelena Koти ECLI:EU:C:2015:833, Case C368/16 Assens Havn v Navigators Management (UK) Limited ECLI:EU:C:2017:546, Case C88/17 Zurich Insurance plc, Metso Minerals Oy v Abnormal Load Services (International) Ltd ECLI:EU:C:2018:558, Case C-433/18 ML v OÜ Aktiva Finants still pending.

${ }^{45}$ Council Regulation (EC) No 2201/2003 of 27 November 2003 concerning jurisdiction and the recognition and enforcement of judgments in matrimonial matters and the matters of parental responsibility, repealing Regulation (EC) No 1347/2000. O.J. L338/1 (2003).

${ }^{46}$ Case C-435/06 C ECLI:EU:C:2007:714, Case C-68/07 Kerstin Sundelind Lopez v Miguel Enrique Lopez Lizazo ECLI:EU:C:2007:740, Case C-523/07 A ECLI:EU:C:2009:225, Case C4/14 Christophe Bohez v Ingrid Wiertz. ECLI:EU:C:2015:563, Case C-445/15 PPU $P$ v $Q$ ECLI:EU:C:2015:763.

${ }^{47}$ Regulation (EU) 2015/848 of the European Parliament and of the Council of 20 May 2015 on insolvency proceedings O.J. L141/19 (2015).

${ }^{48}$ Case C-310/14 Nike European Operations Netherlands BV $v$ Sportland Oy, in liquidation ECLI:EU:C:2015:690, Case C-198/18 CeDe Group $A B$ v KAN sp. z o.o., in liquidation ECLI:EU:C:2019:1001.

${ }^{49}$ Case C-554/17 Rebecka Jonsson v Société du Journal L'Est Républicain ECLI:EU:C:2019:124.
} 


\subsection{Lawyers Make EU Civil Procedure Law Come Alive, or not?}

The role of EU law in the legal landscape depends partly on whether lawyers actually use EU law to argue their cases. The European Enforcement Order (EEO) Regulation $^{50}$ illustrates the fact that the discreet EU procedures for cross-border cases are seldom used. In a study on cross-border cases in the EU, the Finnish legal professionals interviewed had never come across an EEO despite the fact that the interviewees were selected among persons with expertise in cross-border proceedings. ${ }^{51}$ The European small claims proceedings and payment order proceedings are also little used. ${ }^{52}$

The number of lawyers who are well-informed of EU civil procedure is low in the Nordic EU countries. In the aforementioned study on cross-border cases, a lawyer working in a law firm serving the business community explained that the firm always contacts a partner firm in the country concerned rather than using EU instruments in cross-border cases. ${ }^{53}$ Unfamiliarity with the discrete EU procedures results in few lawyers using them. The lack of use becomes self-perpetuating — why use a process when nobody else uses it? Some of the judges interviewed in the study lamented that only a small group of judges attend trainings on EU civil procedure and that many attendees already have previous experience working with EU law, while judges with limited knowledge and skills in EU law, who hence need training, do not attend. The trainings could thus contribute to increasing the knowledge gap among judges. Except for cross-border service and taking of evidence, judges and lawyers seldom encounter EU civil procedure law; thus, they think of EU civil procedure law as something that is 'technical' and useful only for a few lawyers specialising in crossborder litigation. This contributes to a perception that EU law is almost irrelevant in the domain of civil justice.

\subsection{Conclusions on EU Law and Nordic Lawyers}

Nordic lawyers are aware of the basic instruments and characteristics of EU law and utilise them when they consider them appropriate and relevant. It is clear that Nordic court culture has become Europeanised and that Nordic courts apply European substantive law regularly. Nonetheless, the general level of knowledge is superficial and is limited to the most commonly used instruments and situations where the dissonance between national law and EU law is clear. Still, we should not infer that Nordic courts apply EU law less efficiently than do courts in other European

\footnotetext{
${ }^{50}$ Regulation (EC) No 805/2004 of the European Parliament and of the Council of 21 April 2004 creating a European Enforcement Order for uncontested claims O.J. L143/1 (2004).

${ }^{51}$ Gascón Inchausti et al. (2017).

${ }^{52}$ Ervo (2019), pp. 88-90.

${ }^{53}$ Gascón Inchausti et al. (2017).
} 
countries. On the contrary, there is reason to believe that judges across Europe have limited knowledge of EU law and that their encounters with EU law are scarce. ${ }^{54}$

The high interest in EU civil procedure among legal academics has not translated into a high level of knowledge among lawyers and judges. One reason for this discrepancy could be that a significant portion of the writings are in English and the intended audience is international, while Nordic lawyers seldom read English language texts. Handbooks and commentaries, where lawyers and judges would find information related to the specific hard law provisions or specific CJEU rulings in Nordic languages, could enable judges to access information more efficiently. Mainstreaming European civil procedure law in textbooks on civil procedure could also be helpful.

\section{Transposing of EU Civil Procedure in Nordic Law}

\subsection{Implementation of EU Hard Law in Nordic Legislation}

Although Nordic legislators implement EU law loyally, the quality of implementation does not always suffice. EU procedural law that is fragmental, is sectoral or contains concepts and ideas that are not fully concordant with national law necessitates careful analysis before it is transposed into law, so as to uphold the coherence of national law.

In the Nordic countries, the method of implementation of EU law is often haphazardly chosen. For instance, the rules on disclosure of evidence in actions for infringement of intellectual property rights are incorporated in the Norwegian Dispute Act, while corresponding rules for competition law will be implemented in the Competition Act. ${ }^{55}$ The preparatory works do not provide reasons for selecting a specific method of implementation. ${ }^{56}$ Although the rules on disclosure for competition and intellectual property rights are not identical, transposing them in different ways augments the existing disconnection between them by reducing links between them. ${ }^{57}$ Since the context influences interpretation, the rules on disclosure for intellectual property rights cases are likely to be construed in the light of the general rules of civil procedure, whereas the rules on competition law will be read in the light of substantive competition law. ${ }^{58}$ The result is an atomisation of civil procedure law

\footnotetext{
${ }^{54}$ E.g., Krans and Nylund (2020b), Andrews (2016), Galič (2016), Krans (2016), Piszcz (2016) and Nowak et al. (2011).

${ }^{55}$ Act on competition between undertakings and control with concentrations (Competition Act) Lov om konkurranse mellom foretak og kontroll med foretakssammenslutninger (konkurranseloven) 5 March 2004 no 12.

${ }^{56}$ Hjort (2019).

${ }^{57}$ Petersen (2016), pp. 19-20.

${ }^{58}$ Petersen (2016), pp. 24-25.
} 
where rules applicable only for a specific type of case increasingly reduce the role of general procedural rules.

The rules of evidence are central: They determine inter alia whether or not witnesses must be heard orally and or in written form, the standard of proof and the burden of evidence. ${ }^{59}$ In the Nordic countries, the general rules of evidence apply to all cases, unless special rules have been enacted for a specific type of case. However, EU law does not have a doctrine of evidence; that is, there is no clear baseline definition of the standard of proof, nor a shared idea of how evidence should be presented. ${ }^{60}$ This should be taken into account when implementing EU evidence law in national law.

For instance, the Antitrust Damages Directive ${ }^{61}$ that regulates actions for infringement of competition law contains numerous rules on evidence, including rules on the standard of proof. When these rules are transposed, the legislator should, when applicable, use national terminology rather than the terminology used in the Directive to describe the standard of proof. In the event that the standard of proof does not have an equivalence in national law, new standards of proof that are intelligible to national lawyers should be crafted. None of the legislation implementing the Directive in the Nordic EU Member States ${ }^{62}$ includes any reference to the standard of proof. The Finnish implementing act even makes a reference to the general rules on evidence in the Code of Judicial Procedure. In the absence of specific rules on the standard of proof, Nordic lawyers will most likely apply their national rules and doctrines. The transposing legislation mentions other aspects of evidence, such as disclosure, but evidence is not comprehensively regulated. Since EU law is implemented as if there was a single European doctrine of evidence and as if the national doctrine fully corresponds to it, discrepancies are likely to be overlooked, and judges and lawyers will be unlikely to detect them. National evidence law will influence the type and amount of admissible evidence as well as the form (i.e., oral or written) in which the evidence is presented, which will consequently impact the outcome of the case.

Nordic cooperation could improve the quality of implementation of EU hard law. The basic tenets of procedural law are similar in the Nordic countries to provide a fertile ground for analysing possible discrepancies between national law and EU law and finding the most appropriate method of implementation. Cooperation does not necessitate all five countries embracing identical solutions; rather, the aim should be to provide a sound basis for decision-making. Furthermore, active cooperation could

\footnotetext{
${ }^{59}$ For an overview of the standards of evidence in Nordic law, see Strandberg (2019).

${ }^{60}$ Example, the Brussels I bis Regulation O.J. L351/1 (2012), Payment Order Regulation O.J. L399/1 (2006), and the Damages Directive O.J. L349/1 (2014). For a more detailed discussion, see Hau (2020).

${ }^{61}$ Directive 2014/104/EU of the European Parliament and of the Council of 26 November 2014 on certain rules governing actions for damages under national law for infringements of the competition law provisions of the Member States and of the European Union O.J. L349/1 (2014).

${ }^{62}$ The Danish Act on Actions for Infringement of Competition Law (Lov om behandling af erstatningssager vedrørende overtædelser af konkurrenceretten no. 1541 af 12/12/2106), the Finnish Act on Damages in Competition Law (Laki kilpailuoikeudellisista vahingonkorvauksista 2016/1077) and the Swedish Competition Damages Act (Konkurrensskadelag 2016:964).
} 
also result in the Nordic countries detecting potential weaknesses and pitfalls during the drafting of EU law and, hence, give them the opportunity to address the issues before the legislation is enacted.

\subsection{Transposition of Case Law Based Civil Procedural Law}

Part of EU civil procedure law is based almost exclusively on case law. The doctrine of procedural autonomy ${ }^{63}$ and the duty of courts to apply EU consumer law on their own motion ${ }^{64}$ are paramount examples. Case law-based procedural law is unfamiliar to Nordic lawyers, except for Norwegian lawyers: Nordic courts make law only when the new rules can be derived directly from statutory law or fundamental legal principles. The innate nature of case law is to take two steps forward and one step back, resulting in gradual development and a partly disjointed line of argumentation, which in the context of procedural law is unfamiliar to Nordic lawyers. Furthermore, courts respond to the particular legal and factual issues in each case rather than taking a principled, general approach, resulting in considerable opacity and a need for further clarification. Hence, determining the scope of the obligations on national civil procedure law arising from CJEU case law is rather onerous.

If national statutory law is incompatible with EU law, courts must strive to interpret the national rule in a manner that renders it compatible with EU law. When interpretation does not yield satisfactory results, courts are obliged to give primacy to EU law. Several examples where Nordic courts have failed to align national rules with EU law through interpretation, although such an interpretation is feasible, can be found. Norwegian rules for demanding a security for the liability of costs constitute one example. The Norwegian Dispute Act section 20-11 stated that a party domiciled outside Norway could be required to provide a security unless it would be contrary to Norway's international obligations, but it did not mention the EEA Agreement specifically. Technically, the provision was concordant with EU law, because it clearly included the EEA Agreement. However, Norwegian lower courts regularly required claimants domiciled in EEA countries to provide a security, and they continued to do so even after the Supreme Court ${ }^{65}$ found the practice unlawful. Finally, the EFTA Surveillance Authority demanded that the provision should be amended to explicitly include parties from EEA States. The Norwegian government complied and amended the law. ${ }^{66}$

Another example is the duty of courts to apply EU consumer law on their own motion. Nordic courts already have the power, and partly also a duty, to exercise active judicial guidance. ${ }^{67}$ Hence, one could conclude that judicial guidance as is it

\footnotetext{
${ }^{63}$ Krans and Nylund (2020a, b).

${ }^{64}$ Example, Wallerman Ghavanini (2020) and Andersson (2019).

${ }^{65}$ HR-2014-377-U.

${ }^{66}$ Hjort (2019), pp. 114-116.

${ }^{67}$ E.g., Wallerman Ghavanini (2020), Andersson (2019) and Fredriksen and Strandberg (2019).
} 
is regulated in Nordic procedural law fulfils these obligations. However, there are several caveats. First, most consumer cases are dealt with outside the courts or in simplified proceedings, such as orders for payment proceedings. In these proceedings, the case documents are not available to the court. This could be problematic, particularly in the wake of the CJEU ruling in the Bondora case. ${ }^{68}$ Second, the fact that the consumer remains passive in most cases, which hinders the court from giving active guidance, entails a further complication in many consumer cases. ${ }^{69}$ Third, even when both parties are active, the duty to judicial guidance based on EU law probably exceeds the minimum requirements of national law, at least in some situations. However, judges appear to lack awareness of possible differences between national law and EU law, ${ }^{70}$ in the same way as in the Norwegian case on a security for legal costs. Thus, resorting to judicial guidance is not a panacea; rather, the Nordic legislators should assess whether current legislation complies with the obligations under EU law. ${ }^{71}$

In consumer cases, vigilant staff handling simplified cases and judges supervising them are pivotal, as the Finnish Supreme Court ruling KKO 2015:60 72 illustrates. In the case, a consumer credit company filed a simplified claim against a consumer. The consumer did not file a statement of defence, although the late payment interest rate was $118 \%$ and the terms for determination of the rate were unclear. The district court rejected the late payment interests, since the terms of the interest were not compliant with the Unfair Terms Directive. ${ }^{73}$ The consumer credit company appealed, first to the Court of Appeals and then to the Supreme Court, while the consumer remained passive. The Supreme Court held for the consumer: it obligated courts to analyse the case file in their own motion. However, this case is likely to be exceptional, both since the court spotted the unfair term and since the consumer credit company persistently pursued the case. Although the ruling entails clarification of some issues, many other issues remain unresolved.

Despite the challenges that CJEU case law has caused for consumer cases, Nordic lawmakers have not been inclined to explore the problems and weaknesses of their current systems. As Anna Wallerman Ghavanini has noted, complex issues are left to the courts to solve despite the fact that the workload prevents judges from actively

The Nordic rules on judicial guidance are similar to the German rules on die materielle Prozessleitung.

${ }^{68}$ Joined Cases C-453/18 and C-494/18 Bondora AS v Carlos V. C. and XY, Judgment of the Court of 19 December 2019, ECLI:EU:C:2019:1118.

${ }^{69}$ Andersson (2019).

${ }^{70}$ Wallerman Ghavanini (2020).

${ }^{71}$ Wallerman Ghavanini (2020), Andersson (2019), Fredriksen and Strandberg (2019) and Nylund (2019).

${ }^{72}$ See also Mäenpää (2016).

${ }^{73}$ Council Directive 93/13/EEC of 5 April 1993 on unfair terms in consumer contracts O.J. L95/29 (1993). 
searching for unfair terms and that problems arise from institutional structures and regulation rather than how work is organised within courts. ${ }^{74}$

\subsection{Conclusions on the Transposition of EU Civil Procedure Law}

The Nordic countries implement EU law diligently and, in the case of Norway (and Iceland), sometimes opt to implement EU law even when they have no formal obligation to do so. ${ }^{75}$ Consequently, the problem is the mode and quality of implementation, particularly with regard to the fact that much of the adaptation is left to the judiciary. While Nordic judges are accustomed to flexible norms and to weighing, balancing and harmonising principles and rules, the marked differences in approach between EU law and national civil procedure law are not easily bridged through interpretation alone. Makeshift implementation adds up to a patchwork that erodes the system from within. Systematic changes could be put in place to reduce the number of times the jack-in-the-box of EU law pops up and to help retain comprehensive, coherent Nordic court cultures. However, one should not infer that the quality of implementation of EU law is solely Nordic problem: on the contrary, it appears to be omnipresent. ${ }^{76}$

\section{Navigating When the Map and the Terrain Do Not Match}

\subsection{Lost Opportunities for Developing Nordic Civil Procedure Law}

Overlooking the density and potential impact of European civil procedural law has several detrimental consequences related to the development of national law.

EU law contains several procedural innovations, such as court-connected mediation, disclosure of documents, and collective redress, that should be regarded as potential benchmarks. For example, court-connected mediation was introduced in Finland partly as a result of the Civil Mediation Directive. ${ }^{77}$ Steps had already been taken to enact rules on court-connected mediation, and EU law served as an additional argument to propel the reform. Although the Directive only mandates providing court-connected mediation in cross-border cases, Finland-and many

\footnotetext{
${ }^{74}$ Wallerman Ghavanini (2020).See also, e.g., Andersson (2019), Fredriksen and Strandberg (2019), Rudanko (2016) and Savola (2016).

${ }^{75}$ Nylund (2020).

${ }^{76}$ Krans and Nylund (2020b).

${ }^{77}$ Directive 008/52/EC of the European Parliament and of the Council of 21 May 2008 on certain aspects of mediation in civil and commercial mattersO.J. L136/1 (2008).
} 
other Member States-opted to extend mediation to all civil cases. The impact on Finnish court proceedings and court culture has been palpable, as Kirsikka Linnanmäki demonstrates in her chapter in this volume. ${ }^{78}$

However, there are numerous examples of lost opportunities of benchmarking. For example, the Norwegian government did not use the Civil Mediation Directive to assess its court-connected mediation regime. One probable reason for this is that the Dispute Act had been adopted a few years earlier, and thus the time was not ripe for revising the rules. Still, any amendments resulting from benchmarking could have been enacted a few years later simultaneously with other changes. Unlike in EU Member States, agreements to mediate a dispute before litigation are not enforceable in Norway. Furthermore, out-of-court mediation does not influence limitation and prescription periods in Norway, which could deter the parties from attempting to mediate before starting court proceedings. ${ }^{79}$ Thus, out-of-court mediation is less favourably treated in Norway than in many other European countries.

The European Payment Order Procedure ${ }^{80}$ and the European Small Claims Procedure are other examples of lost opportunities to improve national legislation. Despite the fact that Finnish law does not have fully-fledged payment order proceedings and has no small claims proceedings at all, the European procedures were not used to discuss whether Finnish procedural rules should be coordinated with EU procedures and whether EU procedures had any tangible advantages vis-à-vis national procedures. Non-harmonisation, as well as harmonisation, should ensue from a deliberate choice and comparison of the rules: it should not be the result of a haphazard process.

\subsection{The Missing Nordic Input in the Development of EU Civil Procedure Law}

The magnitude of the Europeanisation of civil procedure law should induce national governments to act proactively by attempting to influence the content of EU civil procedure law at an early stage (i.e., before rules are enacted) ${ }^{81}$ Several methods could be used, often in parallel. Whitepapers, green papers and other policy documents should be scrutinised to recognise issues that are pertinent from a Nordic perspective. The Nordic governments could consequently argue why a solution on the EU level is redundant, why a different solution would be superior to the one proposed by the EU, why some solutions are problematic for Nordic law, or any combination of these. The Nordic countries could also position themselves as innovators by strategically enacting innovations.

\footnotetext{
${ }^{78}$ Linnanmäki (2021).

${ }^{79}$ E.g., Nylund (2017a) and Bernt (2015).

${ }^{80}$ Regulation (EC) No 1896/2006 of the European Parliament and of the Council of 12 December 2006 creating a European order for payment procedure O.J L399/1 (2006).

${ }^{81}$ Stadler (2018), p. 777.
} 
Nordic cooperation is the key to increasing the quality of implementation and the quality of EU civil procedure law. It is unfeasible for a single Nordic country to be proactive in multiple legal fields. Therefore, the Nordic countries should join forces to detect potentially problematic issues early, advance Nordic viewpoints and, when necessary, lobby for specific solutions. Additionally, formal Nordic cooperation in the field of civil procedure could make the Nordic countries a powerhouse of innovation. Pilot projects could be designed across the countries; for example, one country could pilot one model and another country could pilot another model. The results could then be contrasted to optimise one or both models. As a result, Nordic countries could be a European trailblazer, and Nordic innovations could serve as a blueprint for EU law.

\subsection{Nordic Cooperation as a Method of Improving Quality}

EU civil procedure law exerts substantial influence on Nordic civil procedure law and Nordic court culture. Europeanisation does not abolish the need for Nordic cooperation; in fact, the opposite is true. Nordic cooperation, both formal and informal, at all stages of the process of Europeanisation could enable us to foresee and prepare for the challenges that lie ahead by influencing EU law. ${ }^{82}$ It could also enable us to ameliorate problems arising from Europeanisation and to reduce the tensions between Nordic law and legal culture and European law. The first step should be to recognise that our map does not fit the terrain and to take Europeanisation seriously.

\section{References}

Adler-Nissen R (2015) Through the EU's front and back doors: the selective Danish and Norwegian approaches in the area of freedom, security and justice. In: Grøn CH, Nedergaard P, Wivel A (ed) The Nordic Countries and the European Union: still the other European Union? Routledge, Abingdon, pp 212-229

Andersson T (1997) Rättsskyddsprincipen. Iustus förlag, Uppsala

Andersson T (2019) Ex officio application of the unfair terms directive cases against consumers: a Swedish perspective. In: Nylund A, Strandberg M (eds) Civil procedure and harmonisation of law: the dynamics of EU and international treaties. Intersentia, Cambridge, pp 153-170

Andrews N (2016) European influences upon English civil justice: tempests or gentle breezes? The European Union and national civil procedure. In: Nylund A, Krans B (eds) The European Union and National Civil Procedure. Intersentia, Cambridge, pp 31-46

Bang-Pedersen UR, Christensen LH, Petersen CS (2017) Den civile retspleje. Hellerup, Pejus

Barnard C (2014) Reciprocity, homogeneity and loyal cooperation: dealing with recalcitrant national courts? In: The EFTA Court (ed) The EEA and the EFTA courts. Decentered integration. Hart, Oxford, pp 151-168

\footnotetext{
${ }^{82}$ Leino-Sandberg and Leppävirta (2018).
} 
Bernitz U (2012) Preliminary references and Swedish courts: what explains the continuing restrictive attitude? In: Cardonnel P, Rosas A, Wahl N (eds) Constitutionalising the EU judicial system. Essays in honour of Pernilla Lindh. Hart, Oxford, pp 177-187

Bernitz U (2018) Preliminary rulings to the CJEU and the Swedish judiciary: current developments. In: Derlén M, Lindholm J (eds) The court of justice of the European Union: multidisciplinary perspectives. Hart Publishing, Oxford, pp 17-34

Bernt C (2011) Meklerrollen ved mekling i domstolene. Fagbokforlaget, Bergen

Bernt C (2015) Mediation of legal disputes in Norway. Institutionalized, pragmatic and increasingly popular. In: Esplugues C, Marquis L (eds) New developments in civil and commercial mediation. Springer, Cham, pp 511-545

Björgvinsson DT (2007) Application of article 34 of the ESA/Court Agreement by Icelandic courts. In: Monti M, von und zu Liechtenstein PN, Vesterdorf B, Westbrook J, Wildhaber L (eds) Economic law and justice in times of globalisation. Festschrift for Carl Baudenbacher. Nomos Verlag, Baden-Baden, pp 37-50

Björgvinsson DT (2014) Fundamental rights in EEA law. In: The EFTA court (ed) The EEA and the EFTA courts. Decentered integration. Hart, Oxford, pp 263-280

Bobek M (2010) Why there is no principle of procedural autonomy of the member of states. RRDE 36

Boucht J (2014) Introduction to Finnish and Swedish legal method. In: Helland I, Koch S (eds) Nordic and Germanic legal methods. Mohr Siebeck, Tübingen, pp 165-187

Broberg M, Fenger N (2013) Variations in member states' preliminary references to the court of justice: are structural factors (part of) the explanation? Eur Law J 19(4):488-501

Broberg M, Fenger N (2015) Förhandsavgöranden från svenska domstolar: Är svenska domstolar väsentligt mindre benägna att begära förhandsavgöranden än domstolar i andra medlemsstater? Europarättslig Tidskrift 18(4):769-790

Bylander E (2006) Muntlighetsprincipen: en rättsvetenskaplig studie av processuella handläggningsformer i svensk rätt. Iustus förlag, Uppsala

Bylander E (2017) Regeringsformens krav på alla rättegångars genomförande rättvist och inom skälig tid. Svensk Juristtidning 102(5-6):370-398

Derlén M, Lindholm J (2017a) Från Champagne till Ramlösa: EU-domstolens rättspraxis i svenska underinstanser. Europarättslig Tidskrift 4: 695-716

Derlén M, Lindholm J (2017) Serving two masters: CJEU case law in Swedish first instance courts and national courts of precedent as gatekeepers. In: Derlén M, Lindholm J (eds) The court of justice of the European Union: multidisciplinary perspectives. Hart Publishing, Oxford, pp 79-100

Dougan M (2004) National remedies before the court of justice: issues of harmonisation and differentiation. Hart, Oxford

Ervo L (2005) Oikeudenmukainen oikeudenkäynti. WSOY, Vantaa

Ervo L (2019) Harmonisation or fragmentation of national law? An East Nordic perspective. In: Nylund A, Strandberg M (eds) Civil procedure and harmonisation of law: the dynamics of EU and international treaties. Intersentia, Cambridge, pp 77-98

Ervo L (2020) The Finnish way of understanding procedural autonomy: a practical approach to implementing EU civil procedural law. In: Krans B, Nylund A (eds) Procedural Autonomy across Europe. Intersentia, Cambridge, pp 57-80

Fenger N, Rydelski MS, van Stiphout T (2012) European Free Trade Association (EFTA) and European Economic Area (EEA). Wolters Kluwer, Alphen aan den Rijn

Frände D, Havansi E, Helenius D, Koulu R, Lappalainen J, Lindfors H, Niemi J, Rautio J, Virolainen J (2012) Prosessioikeus. SanomaPro, Helsinki

Franklin CNK (ed) (2018) The effectiveness and application of EU and EEA law in national courts: principles of consistent interpretation. Intersentia, Cambridge

Fredriksen HH (2008) Tvisteloven og EØS-Avtalen. Tidsskrift for Rettsvitenskap 121(3):289-359

Fredriksen HH (2009) Europäische Vorlageverfahren und nationales Zivilprozessrecht: eine Untersuchung der Vorlageverfahren an den EFTA-Gerichtshof und den EuGH als Bestandteile des norwegischen bzw. des deutschen Zivilprozesses. Mohr Siebeck, Tübingen 
Fredriksen HH (2010) One market, two courts: legal pluralism vs. homogeneity in the european economic area. Nordic J Int Law 79(4):481-499

Fredriksen HH (2011) EU/EØS-rett i norske domstoler. Europautredningen. Utvalget for utredningen av Norges avtaler med EU, Oslo

Fredriksen HH (2012) Bridging the widening gap between the EU Treaties and the agreement on the European economic area. Eur Law J 18(6):868-886

Fredriksen HH (2016) Høyesterett som EØS-domstol. In: Skoghøy JEA, Øie TM, Matningsdal M (eds) Rettsavklaring og rettsutvikling - Festskrift til Tore Schei. Universitetsforlaget, Oslo, pp 438-464

Fredriksen HH (2018) The EFTA court. In: Howse R, Ruiz-Fabri H, Ulfstein G, Zang MQ (eds) The legitimacy of international trade courts and tribunals. Cambridge University Press, Cambridge, pp 138-181

Fredriksen HH, Franklin CNK (2015) Of pragmatism and principles: the EEA agreement 20 years on. Common Mark Law Rev 52:629-684

Fredriksen HH, Strandberg M (2018) Norwegian civil procedure under the influence of EU law. In: Uzelac A, van Rhee CHR (eds) Transformation of civil justice: unity and diversity. Springer , Cham, pp 41-62

Fredriksen HH, Strandberg M (2019) Ex officio application of EU consumer protection law in Norwegian courts. In: Nylund A, Strandberg M (eds) Civil procedure and harmonisation of law: the dynamics of EU and international treaties. Intersentia, Cambridge, pp 171-191

Galič A (2016) Slovenian civil procedure and the transformative power of the EU. In: Nylund A, Krans B (eds) The European Union and national civil procedure. Intersentia, Cambridge, pp $131-146$

Galič A (2020) Procedural autonomy between EU law and the Slovenian law of civil procedure. In: Krans B, Nylund A (eds) Procedural autonomy across Europe. Intersentia, Cambridge, pp $165-182$

Gascón Inchausti F, Hess B, Cuniberti G, Oberhammer P, Reqejo Isidro M, Weitz K, Storskrubb E, Kramer X (2017) An evaluation study of national procedural laws and practices in terms of their impact on the free circulation of judgments and on the equivalence and effectiveness of the procedural protection of consumers under EU consumer law. Strand 1: mutual trust and free circulation of judgments. Brussels, European Commission

Hau W (2020) Who is afraid of European civil procedure? A German perspective on the waning procedural autonomy of the member states. In: Krans B, Nylund A (eds) Procedural autonomy across Europe. Intersentia, Cambridge, pp 81-100

Helgadóttir R (2011) Nonproblematic judicial review: a case study. Int J Const Law 9(2):532-547

Helland I, Koch S (2014) Introduction to Norwegian legal method. Nordic and Germanic legal methods: contributions to a dialogue between different legal cultures, with a main focus on Norway and Germany. In: Helland I, Koch S (eds) Nordic and Germanic legal methods. Mohr Siebeck, Tübingen, pp 99-140

Hess B, Bergström M, Storskrubb E (eds) (2016) EU civil justice: current issues and future outlook. Swedish studies in European law. Hart, Oxford

Hjort MA (2019) The EU's Iinfluence on Norwegian civil procedure through national substantive law. Civil procedure and harmonisation of law. In: Nylund A, Strandberg M (eds) Civil procedure and harmonisation of law: the dynamics of EU and international treaties. Intersentia, Cambridge, pp 111-124

Hreinsson P (2012) The interaction between Iceland courts and the EFTA court. In: The EFTA Court (ed) Judicial protection in the European economic area. German Law Publishers, Stuttgart, pp 90-99

Husa J (2000) Guarding the constitutionality of laws in the Nordic countries: a comparative perspective. Am J Comparat Law 48(3):345-381

Husa J (2019) Constitutional mentality. In: Letto-Vanamo P, Tamm D, Mortensen BOG (eds) Nordic law in European context. Springer, Cham, pp 41-60

Jääskinen N (2005) Internationella normer i nordisk rätt. Europarättslig tidskrift (3):520-531 
Knuts G (2006) Förfarandegarantier vid domstolsanknuten medling. Suomen lakimiesyhdistyksen kustannus, Helsinki

Krans B (2015) EU law and national civil procedure law: an invisible pillar. Eur Rev Private Law 23(4):567-587

Krans B (2016) The impact of EU law on Dutch civil procedure law. In: Nylund A, Krans B (eds) The European Union and national civil procedure. Intersentia, Cambridge, pp 89-100

Krans B (2020) Procedural autonomy in the Netherlands: a fading relic? In: Krans B, Nylund A (eds) Procedural autonomy across Europe. Intersentia, Cambridge, pp 101-118

Krans B, Nylund A (2020) Aspects of Procedural autonomy. In: Krans B, Nylund A (eds) Procedural autonomy across Europe. Intersentia, Cambridge, pp 1-11

Krans B, Nylund A (2020) Comparative insights on procedural autonomy. In: Krans B, Nylund A (eds) Procedural autonomy across Europe. Intersentia, Cambridge, pp 227-244

Lang JT (2017) The principle of sincere cooperation in EEA Law. In: Baudenbacher C (ed) The fundamental principles of EEA law. Springer, Cham, pp 73-89

Leijon K, Karlsson C (2013) Nationella domstolar som politiska aktörer: främjare av rättslig integration eller försvarare av nationella intressen? Statsvetenskaplig Tidskrift 115(1):5-34

Leino-Sandberg PSM, Leppävirta LH (2018) Does staying together mean playing together? The influence of EU law on co-operation between EU and non-EU States: the Nordic example. Eur Law Rev 43(3):295-312

Lindfors H (2017) Poistuvan eksekvatuurin aika ja sen vaikutukset Bryssel Ia-asetuksen oikeussuojajärjestelmään. In: Riekkinen J (ed) Oikeutta oikeudenkäynnistä täytäntöönpanoon: Juhlajulkaisu Tuula Linna. Helsinki, Alma Talent, pp 209-220

Linna T (2016) Bryssel I-asetuksen ja välimiesmenettelyn suhde. Defensor Legis 97(2):178-185

Linna TH (2015) Actio pauliana and res judicata in EU insolvency proceedings. J Private Int Law 11(3):568-584

Linnanmäki K (2021) Mediation: a change in Finnish court culture? In: Ervo L, Letto-Vanamo P, Nylund A (eds) Rethinking Nordic Courts. Springer, Cham

Mäenpää K (2016) Kuluttajaluoton koron kohtuullisuus ja tuomioistuimen tutkimisvelvollisuusKKO 2015:60. Lakimies 114(2):336-343

Magnússon S (2014) Efficient judicial protection of EEA rights in the EFTA pillar: different role for the national judge? In: The EFTA court (ed) The EEA and the EFTA courts. Decentered integration. Oxford, Hart, pp 117-132

Martinsen DS, Wind M (2010) When national courts go to Europe: reluctant or active players in the integrationsprocess? In: Koch H, Hagel-Sørensen K, Haltern U, Weiler JHH (eds) Europe. The new legal realism. Essays in honour of Hjalte Rasmussen. DJØF Publishing, Copenhagen, pp 479-500

Miettinen S (2019) Duties to refer duties: the commission investigates whtether Finnish supreme courts failed to refer tax cases to the court of justice. Europarättslig tidskrift (2):245-260

Nergelius J (2009) Judicial review in Swedish law: a critical analysis. Nordic J Hum Rights 27(2):142-159

Nowak T, Amtenbrink F, Hertogh M, Wissink M (2011) National judges as European Union judges: knowledge, experiences and attitutdes of lower court jduges in Germany and the Netherlands. Eleven International Publishing, Den Haag

Nylund A (2016) Norway: an insider outside—or an outsider inside-European civil justice. In: Nylund A, Krans B (eds) The European Union and national civil procedure. Intersentia, Cambridge, pp 101-114

Nylund A (2017a) Civil procedure Norway. Kluwer Law International, Alphen aan den Rijn

Nylund A (2017) Sak samma om det är samma sak? Tidskrift Utgiven Av Juridiska Föreningen i Finland 153(2-4):345-359

Nylund A (2019) Comparing the efficiency and quality of civil justice in Scandinavia: the role of structural differences and definitions of quality. Civ Just Q 38(4):427-439 
Nylund A (2020) Procedural autonomy, the EEA agreement and Norwegian law: the art of bridging a gap and maintaining it too. In: Krans B, Nylund A (eds) Procedural autonomy across Europe. Intersentia, Cambridge, pp 119-138

Nylund A, Strandberg M (2019) Introduction. In: Nylund A, Strandberg M (eds) Civil procedure and harmonisation of law: the dynamics of EU and international treaties. Intersentia, Cambridge, pp $1-10$

Nylund A, Strandberg M (2019) Conclusions on civil procedure and harmonisation of law. In: Nylund A, Strandberg M (eds) Civil procedure and harmonisation of law: the dynamics of EU and international treaties. Intersentia, Cambridge, pp 231-242

Ojanen T (2009) From constitutional periphery toward the center: transformations of judicial review in Finland. Nordic J Hum Rights 27(2):194-207

Örlygsson T (2007) Iceland and teh EFTA court: twelve years of experience. In: Monti M, von und zu Liechtenstein PN, Vesterdorf B, Westbrook J, Wildhaber L (eds) Economic law and justice in times of globalisation. Festschrift for Carl Baudenbacher. Nomos Verlag, Baden-Baden, pp 225-242

Petersen CS (2016) Danish civil procedure and the internal market: impact and challenges of sectoral harmonisation. In: Nylund A, Krans B (eds) The European Union and national civil procedure. Intersentia, Cambridge, pp 17-30

Petersen CS, Schovsbo JH (2018) Decision-making in the unified patent court: ensuring a balanced approach. In: Geiger C, Nard CA, Seuba X (eds) Intellectual property rights and the judiciary. Edward Elgar Publishing, Cheltenham, pp 37-57

Piszcz A (2016) Polish civil proceedings: how much Europeanised? In: Nylund A, Krans B (eds) The European Union and national civil procedure. Intersentia, Cambridge, pp 115-130

Poulsen TC (2016) Norwegian courts. In: Baudenbacher C (ed) The handbook of EEA law. Springer, Cham, pp 257-275

Prechal S, Cath K (2014) The European acquis of civil procedure: constitutional aspects. Uniform Law Rev 19(2):179-198

Rudanko M (2016) Kohti kuluttajaprosessioikeutta: kuluttajaluottojen korot ja tuomioistuinten tutkintavalta. Lakimies 114(6):879-906

Rytter JE, Wind M (2011) In need of juristocracy? The silence of Denmark in the development of European legal norms. Int J Const Law 9(2):470-504

Šadl U, Wallerman A (2019) 'The referring court asks, in essence': Is reformulation of preliminary questions by the court of justice a decision writing fixture or a decision-making approach? Eur Law J 25(4):416-433

Sand IJ (2009) Judicial review in Norway under recent conditions of European law and international human rights law-a comment. Nordisk Tidsskrift for Menneskerettigheter 27:160-169

Savola P (2016) Hylätään selvästi perusteettomana: tuomioistuimen tutkimisvallasta erityisesti kuluttaja-asioissa. Lakimies 114(1):53-76

Schaumburg-Müller S (2009) Parliamentary precedence in Denmark: a jurisprudential assessment. Nordisk Tidsskrift for Menneskerettigheter 27:170-184

Sigurbjörnsson M (2014) To refer or not to refer? In: The EFTA court (ed) The EEA and the EFTA courts. Decentered Integration. Hart, Oxford, pp 101-106

Skoghøy JEA (2011) Dommerrollen gjennom de siste 50 år: noen utviklingstrekk. Lov og Rett 50(01-02):4-24

Spano R (2017) The EFTA court and fundamental rights. Eur Const Law Rev 13(3):475-492

Stadler A (2018) Book review: the European Union and national civil procedure. Rabels Zeitschrift Für Ausländisches Und Internationales Privatrecht 81:773-777

Storskrubb E (2008) Civil procedure and EU law: a policy area uncovered. Oxford University Press, Oxford

Storskrubb E (2017) Några tankar om hur EU-rättens tentakler genomtränger processrätten. Tidskrift Utgiven Av Juridiska Föreningen i Finland 153(2-4):360-383 
Storskrubb E (2017b) Tillit mellan rättssystemen i EU: det civilrättsliga perpektivet. In: Bakardjieva Engebrekt A, Michalski A, Oxelheim L (eds) Tilliten i EU vid ett vägskäl. Santerus Academic Press, Falun

Storskrubb E (2018) Mutual trust and the dark horse of civil justice. Camb Yearb Eur Leg Stud 20:179-201

Storskrubb E (2019) EU civil justice at the harmonisation crossroads? In: Nylund A, Strandberg M (eds) Civil procedure and harmonisation of law: the dynamics of EU and international treaties. Intersentia, Cambridge, pp 11-34

Storskrubb E (2019b) Mutual trust in civil justice cooperation in the EU. In: Bakardjieva Engebrekt A, Bremberg N, Michalski A, Oxelheim L (eds) Trust in the European Union in challenging times. Palgrave Macmillan, pp 159-180

Storskrubb E, Wallerman A (2017) Judicial cooperation in civil matters: coming of age? In: Servent AR, Trauner F (eds) The Routledge handbook of justice and home affairs research. Routledge, Abingdon, pp 203-214

Strandberg M (2019) Standards of evidence in Scandinavia. In: Tichý L (ed) Standard of proof in Europe. Mohr Siebeck, Tübingen, pp 135-159

Sunnqvist M (2014) Konstitutonellt kritiskt dömande. Förändringen av nordiska domares attityder under två sekel. Jure, Stockholm

Sunnqvist M (2021) The changing role of Nordic courts. In: Ervo L et al (eds) Rethinking Nordic Courts. Springer, Cham

Temple Lang J (2012) The duty of national courts to provide access to justice in the EEA. In: The EFTA Court (ed) Judicial protection in the European economic area. German Law Publishers, Stuttgart, pp 100-135

Thorsteinsdóttir H (2021) Globalisation and court practice in Iceland: new case law of the Supreme Court in relation to the EEA Agreement and European Convention on Human Rights. In: Ervo L et al (eds) Rethinking Nordic Courts. Springer, Cham

Wallerman A (2015) Om fakultativa regler. En studie av svensk och unionsrättslig reglering av skönsmässigt beslutsfattande i processrättsliga frågor. Iustus förlag, Uppsala

Wallerman A (2016) The curious incident of the dog in the night-time: Europeanisation of civil procedure in Sweden. In: Nylund A, Krans B (eds) The European Union and national civil procedure. Intersentia, Cambridge, pp 147-160

Wallerman A (2016) Towards an EU law doctrine on the exercise of discretion in national courts? The Member States' self-imposed limits on national procedural autonomy. Common Mark Law Rev 53(2):339-360

Wallerman A (2018) Referring court influence in the preliminary ruling procedure: the Swedish example. In: Derlén M, Lindholm J (eds) The court of justice of the European Union: multidisciplinary perspectives. Hart Publishing, Oxford, pp 153-170

Wallerman A (2019a) Can two walk together, except they be agreed? Preliminary references and (the erosion of) national procedural autonomy. Eur law Rev 2:159-177

Wallerman A (2019) Who is the national judge? A typology of judicial attitudes and behaviours regarding preliminary references. In: Rauchegger C, Wallerman A (eds) The eurosceptic challenge national implementation and interpretation of EU law. Hart Publishing, Oxford, pp 155-174

Wallerman Ghavanini A (2020) Manouvering procedural autonomy in Sweden. In: Krans, B, Nylund A (eds) Procedural autonomy across Europe. Intersentia, Cambridge, pp 203-226

Werlauff E (1997) Fælleseuropæisk procesret: europaretlige krav til dansk retspleje. København, Jurist- og Økonomforbundets Forlag

Wilhelmsson T (1997) Jack-in-the-box theory of European Community Law. In: Krämer L, Micklitz HW, Tonner K (eds) Law and diffuse intersts in the European legal order: Liber Amicorum Norbert Reich. Nomos, Baden Baden, pp 177-194

Wind M (2009) When parliament comes first: the Danish concept of democracy meets the European Union. Nordisk Tidsskrift for Menneskerettigheter 27(2):272-288

Wind M (2010) The Nordics, the EU and the reluctance towards supranational judicial review. J Common Mark Stud 48(4):1039-1063 
Wind M (2018) The Scandinavians: the foot-dragging supporters of European law? In: Derlén M, Lindholm J (eds) The court of justice of the European Union: multidisciplinary perspectives. Hart Publishing, Oxford, pp 191-210

Wind M, Martinsen DS, Rotger GP (2009) The uneven legal push for Europe questioning variation when national courts go to Europe. Eur Union Polit 10(1):63-88

Open Access This chapter is licensed under the terms of the Creative Commons Attribution 4.0 International License (http://creativecommons.org/licenses/by/4.0/), which permits use, sharing, adaptation, distribution and reproduction in any medium or format, as long as you give appropriate credit to the original author(s) and the source, provide a link to the Creative Commons license and indicate if changes were made.

The images or other third party material in this chapter are included in the chapter's Creative Commons license, unless indicated otherwise in a credit line to the material. If material is not included in the chapter's Creative Commons license and your intended use is not permitted by statutory regulation or exceeds the permitted use, you will need to obtain permission directly from the copyright holder. 